\title{
The Hermeneutical Value of Bodily Experiences for Art History Research
}

\section{Carlos Idrobo}

One of the most important paradigms of contemporary art is that of the viewer as an active participant in the experience of the artwork. The range of this participation extends from various degrees of physical engagement to the necessity of the viewer's presence to complete the piece - a key concept being that of activation. While this is perhaps more or less evident in many performances and installations that require at least one or two people, and even more so in artistic projects that involve groups or whole communities, engaging physically with an artwork is nevertheless already part of the moment of reception, regardless of the type of art form. But if one essential requirement for the viewer's physical involvement in the art-making process is to have a haptic expe- rience, which cannot be done with paintings in museums or galleries for obvious reasons, it does not explain why an installation like Bruce Nauman's Live-taped video corridor (1969/70) does not entail a viewer touching or grabbing anything with their hands, just to step in and walk back and forth. In other words, it involves a physical action in which the body of the spectator can remain relatively separated from the materiality of the installation without affecting the experience of seeing oneself in one of the monitors. From this - perhaps narrow - point of view, the relationship that the beholder establishes with an installation like Nauman's may not be entirely dissimilar from the one with a painting, although the nature of the aesthetic distance is different. Consequently, is it possible to 'activate' a painting through alternative bodily experiences? And in which way would having experiences of bodily movements contribute to the interpretation of artworks from different periods?

In this paper, I will examine how this paradigm of the active spectator can be applied to the interpretation of a few paintings, mostly of the nineteenth century. I will argue that the practice and/or observation of bodily movements (in daily life) may contribute to expanding our understanding of the event in the image, and that they can be transformed into reception strategies that nurture interpretation and art research. While these bodily experiences can range from playing a musical instrument to practicing a sport to any other set of practices and activities, this paper will focus only on dancing and walking because of their strong prevalence in visual arts. The first section elaborates further on the idea of the explicit viewer in contemporary art, by contrasting two forms of imagery related to dance movements, namely Andy Warhol's 
Dance Diagrams and the dance notations from Rudolf von Laban. The second section discusses the practice of walking in relation to the landscape painting of Caspar David Friedrich, focusing more specifically on his painting Der Watzmann (1824/25). The third and final section shifts into the bodily experiences of observing and experiencing motion in dancing and walking to briefly comment on some paintings by Arnold Böcklin, Carl Gustav Carus, and Carl Spitzweg. I aim at showing how certain bodily experiences are either prompted by the paintings or can be brought about by the spectator to explore unforeseen dimensions in the image. ${ }^{1}$

\section{The Explicit Viewer in Contemporary Art}

In museums where Andy Warhol's Dance Diagrams are exhibited, there is a familiar scene among visitors: occasionally, someone tries to reproduce the bodily movements represented in these images. Made in 1962, with pencil and casein paint on linen and in different sizes, this series of seven "rip-offs" from two dance books titled Lindy Made Easy (with Charleston) and Fox Trot Made Easy (both published in 1956) avoid any resem- blance to a hand-painted canvas. Instead, the hand of the painter worked with the precision of a machine that elided the presence of an author and pushed the boundaries of painting towards graphic art and dance and music $^{2}$ (notation). There is nothing about this series that appeals to an interpretation of its compositional elements. Its destination and tendency points exclusively to the real space that the object shares with its recipient or spectator.

This series cannot be more different and yet so akin to another set of representations of bodily movements called Labanotation, a dance notation system created by Rudolf von Laban in the 1920s and published only in 1928, which later came to be known as Kinetography. ${ }^{3}$ The most interesting part of Labanotation is that it became a pedagogical device for teaching dance at different levels, by allowing a lower to higher complexity and specificity, and by incorporating other important variables such as ground level, duration, rhythm, and tempo. Most notably, it became a device both for creating and recording choreographies, and soon after found an anthropological use: to register the movements of traditional dances of other cultures, that is, an instrument for the accurate preservation of folk dances beyond an educational purpose.

The main similarity between both sets of representations is their basic function: they provide instructions to the viewer to enact a certain dance movement. In this sense, the image needs to be read and performed, and only then it is possible to recognise what it is about. It prompts the beholder to become a dancer. Thus, they resemble a music score in that it is only in the performance that the music takes place. However, the difference between Warhol's notation on one hand, and Labanotation on the other, is easy to spot. Warhol's notation - not his, really - is friendlier and easier to follow for a lay-audience, and far from the cryptic Labanotation, which demands expertise. On a formal level, the first notation only instructs a basic dance step and is limited to the footwork on the surface, whereas the second involves the whole body and expands to all spatial directions.

But it is precisely the incompleteness of the first notation that enables a different relation to the recipient, one that also depends on how each diagram is exhibited, that is, whether hanging on a wall or laying on the 
floor. By limiting the synchronic movement of the feet along the surface, it leaves the movements of the upper torso and arms to the decision of the beholder-turned-dancer. If the notation is hanging on a wall, like the Dance Diagram No. 2 (Fox Trot "The Double Twinkle-Man") 4 at the Andy Warhol Museum in Pittsburgh, it is highly probable that the viewer becomes more attentive and aware of their entire body posture while accommodating their arms and torso to an imaginary dance partner. If the notation is laying on the floor, as initially conceived by Warhol and exhibited for the first time at the Stable Gallery in New York (6 November 1962), the viewer will invariably bend towards the image and focus their attention on the footwork. As Wolfgang Kemp points out, by displaying the diagram on the floor, covered with protective glass, as in a 2003 Exhibition in Frankfurt or at the Broad Museum in Los Angeles (Dance Diagram No. 3 ("The Lindy Tuck-In TurnMan")), ${ }^{5}$ the viewers are compelled to enact the movements of the instructions next to the piece. ${ }^{6}$ This has even prompted educators at the Whitney Museum of American Art in New York to host a workshop with museum visitors to enact and learn the Dance Diagram No. 5
(Fox Trot: "The Right Turn - Man"). ${ }^{7}$ One can imagine that if the notation were to be printed and laid on the floor without any frame or glass, the viewer would literally step on the graphic and follow its movement. But by using the glass, the viewer constantly needs to negotiate and re-evaluate the position and movements of the body in the space and in relation to the notation. This is the moment when the dance takes place, that is, when the invitation to enact the image is accepted and the relation between object and viewer comes to a closure without their ever being in close contact with each other. Its meaning lies in its destination, because only then the viewer will have a sense of the object.

Warhol's dance diagram is an earlier example of an important aspect of contemporary art: the transformation of the beholder into an active participant of the art object. This active participation is here understood not only intellectually, but also physically. As Kemp notices, this went further in the installations of Franz Erhard Walther (see his Werksatz from 2008) $)^{8}$ and Bruce Nauman (see his Live-taped video corridor from 1969/70), ${ }^{9}$ which require the participation of the beholder to activate them. Without this participation, the piece is incomplete. In some cases, installations prompt the beholder not only to walk in front of them, but also through or around them, so that a comprehensive gestalt of its spatial presence can be formed. The art installation, no longer a piece of aesthetic distance, becomes a medium ${ }^{10}$ that releases an experience in which the active participation of the beholder is part of the process. Ontologically speaking, it relies on the immanence of an experience in which both artwork and recipient are aware of each other. And yet, Walther's fabric objects require a direct interaction with the viewer, while most of Nauman's installations do not.

In Warhol's dance diagrams, which also arise from an appropriationist gesture that tends to efface the presence of the artist, the birth of the viewer takes place in the enactment of the dance, namely, in the moment that the image prompts the bodily experience of the fox trot to be (in)formed by specific instructions. This is where Warhol's diagrams are betrayed by their own nature. In the case of the works by Walther or Nauman, the spectator needs to be present every time to experience them. The active participa- 
tion is concomitant to the temporality of the present time, and therefore, this aesthetic experience depends on a shared temporality between artwork and viewer. But with the dance diagrams, once the instructions are followed, the notation would have run its full course, and there would be no need to go back to it, other than to review or rectify possible missteps. This is true of music scores and other dance notations - although some musicians have the discretion of performing with scores, which every so often contain personal annotations written during rehearsals, and no dancer will look at notes while performing. In other words, once a dance step is memorised the diagram becomes rather superfluous. And given that Warhol's diagrams are now scattered across different museums, the full pedagogical function of teaching the fox trot, which was the original function of the source material, remains truncated. The diagrams represent fragmentary steps of a dance that cannot fully take place. To put it bluntly, no spectator will learn the fox trot with one of these images; nor does the fox trot need Warhol or his diagrams. The enactment of the dance and its subsequent learning comes at the cost of both the artist and the image. The birth of the viewer turned dancer is not only at the cost of the appropriationist artist, but also of her work. ${ }^{11}$ The bodily experience of the dance does not provide any means to interpret the image any further. It forecloses the interpretation by enabling a non-verbal experience that becomes independent from them. Whether the artist intended this effacement, of both himself and his work, is not our concern.

Is it then possible to trace back elements of this explicit reception experience in contemporary arts to another period in which the viewer was rather a subordinate of the 'authoritative' discourse of the artist? In the next two sections, I will discuss a few paintings of the nineteenth century that prompt a certain bodily experience in the moment of reception and how the awareness of this kind of engagement with the artwork can be used as a strategy to reveal other aspects in the image.

\section{Walking and Landscape Painting}

It is now accepted that one of the most important traits of Romanticism, especially its German variant, was the simple bodily experience of wandering in nature. Walking oriented or aimlessly was not only a motif,

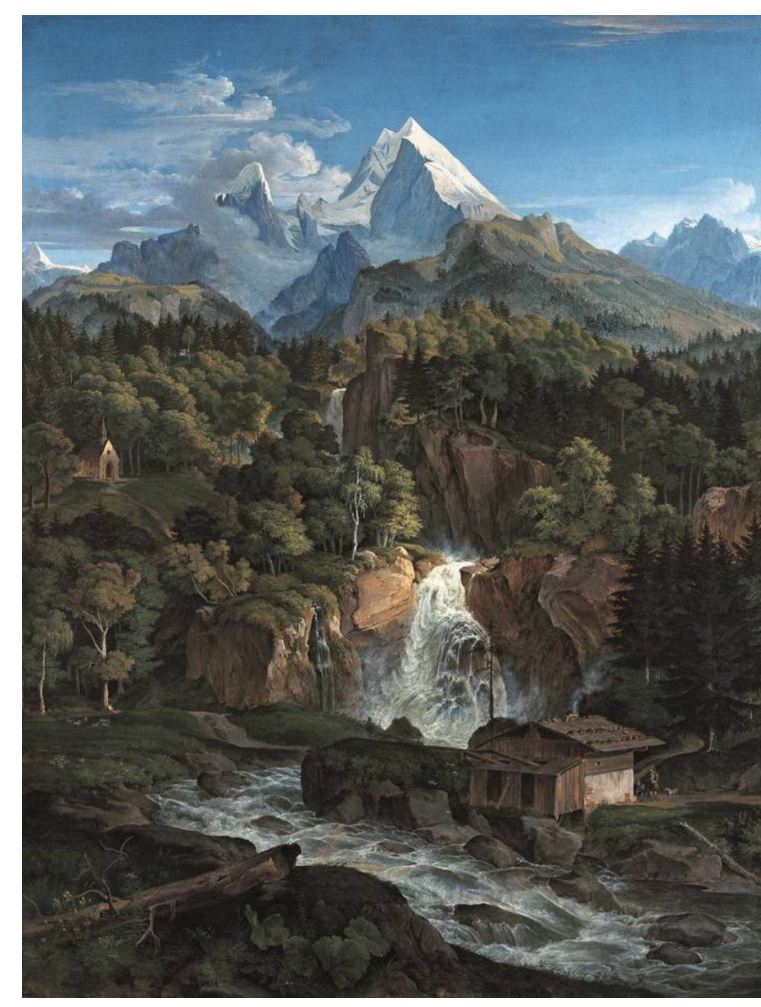

Figure 1. Ludwig Richter, Der Watzmann, 1824. Oil on canvas, 121 x 93,5 cm. Inv. No. 8983. Bayerische Staatsgemäldesammlungen - Neue Pinakothek, Munich. CC BY-SA 4.0.

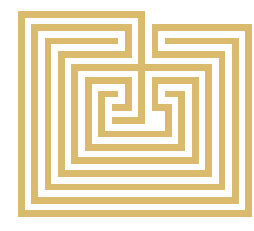


consciously depicted in various forms like paintings, drawings, illustrations, songs, poems, and stories. It also became part of artistic production as such, a practice undertaken by artists to defy the increasing speed of newer forms of mobility and the radical transformation of entire landscapes, which brought altogether new ways of seeing nature. But this walking experience was not intended of the viewer in front of the painting, or at least not physically. Instead, a landscape painting should have been able to prompt an imagined or virtual 'walk' (read 'view') into the horizon of the depicted landscape, without any particular obstructions. ${ }^{12}$ In a word, the landscape needed to be walkable [begehbar]. Take for instance Ludwig Richter's painting of the Watzmann (1824, Fig. 1), ${ }^{13}$ which catapulted the career of this then 21-year-old artist. Created according to the standards of landscape painting of its time and following the teachings of Joseph Anton Koch, this idyllic depiction of the majestic mountain in the Bavarian Alps allows the eye to follow a path all the way from the foreground to the background, pleasantly transitioning from one spatial moment into the next, and in some instances through

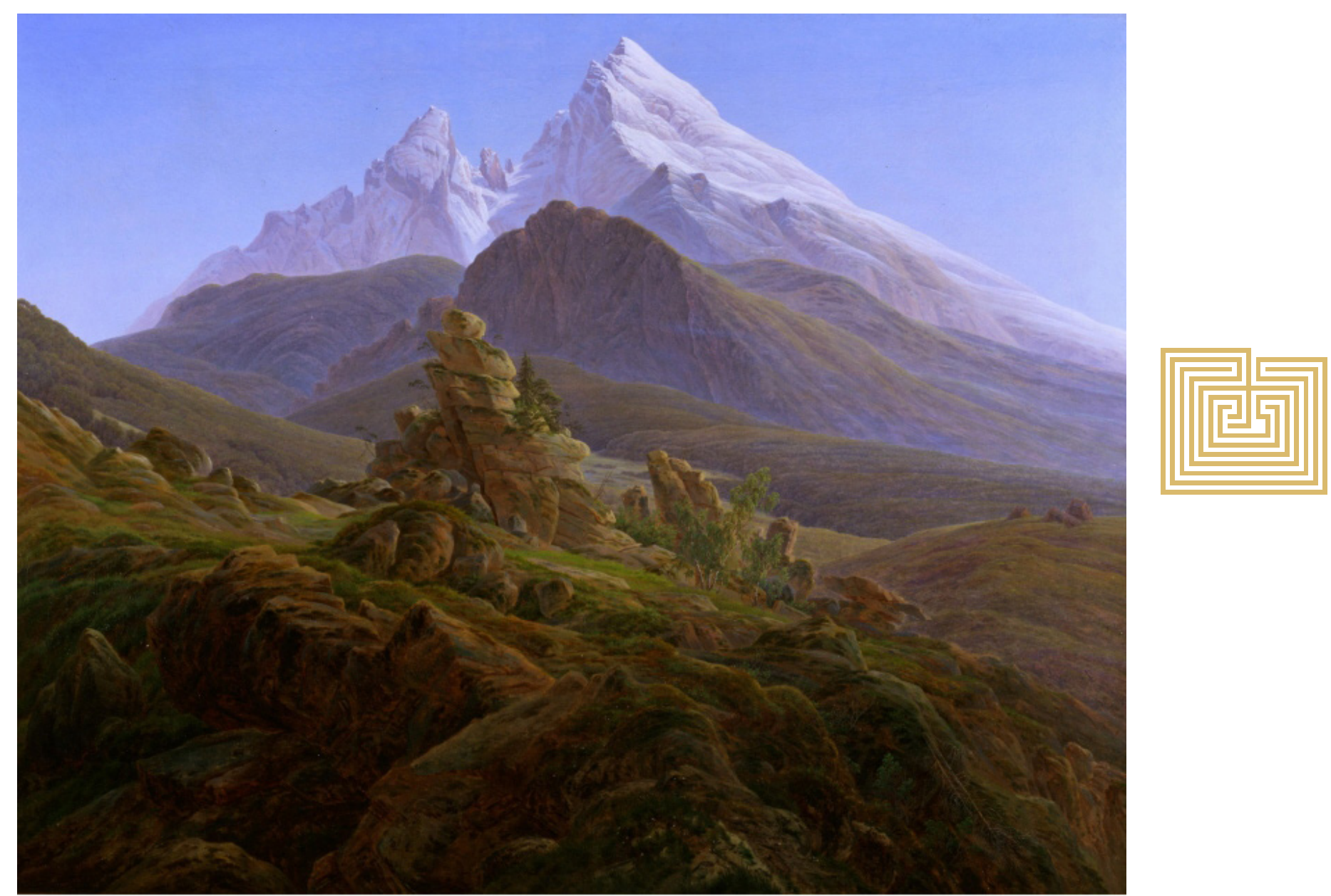

Figure 2. Caspar David Friedrich, Der Watzmann, 1824/1825. Oil on canvas, $135 \times 170$ cm. Inv. No. F.V. 317. Alte Nationalgalerie | Staatlichen Museen zu Berlin - Preußischer Kulturbesitz. Photo: Andres Kilger. CC BY-NC-SA. 
unknown-and perhaps risky—thick, dark forests. All the almighty nature, all the sublimity therein was available for early nineteenth century beholders to penetrate the landscape and get lost in its contemplation. But as with many landscape paintings of the time, it also reflected the human impact on nature. And sooner or later, it was followed by artworks that highlighted the transformation of the landscape through the creation of big structures like bridges and tunnels, which greatly improved the trade of goods. A fitting example is Carl Blechen's Bau der Teufelsbrücke (ca. 1830/32)14 which features the construction of the Devil's Bridge between the Swiss towns of Göschenen and Andermatt. Tunnels and bridges create a different dynamic in space and time, when considered from the point of view of walking and travelling. They are literally static figures that accelerate travelling and compress the landscape. In a way, this also changed the penetration of a painted landscape: the eye was able to find faster routes to follow.

But when Caspar David Friedrich entered the art scene in Dresden at the turn of the nineteenth century and started developing his own style, his attempts at disrupting the traditional way of perceiving landscape painting ended up in controversy. And this was still the case by the time he finished his own rendition of Der Watzmann around 1824/25 (Fig. 2), ${ }^{15}$ which appeared soon after Richter's. The two depictions of the same Bavarian mountain had only a few things in common: they were not conceived on location but through second-hand depictions, which resulted in different imagined foregrounds. ${ }^{16}$ But for viewers of the time, who were more familiar with the usual secure position for the contemplation of a landscape given in Richter's work, and in the works of the German artists living in Rome, moving seamlessly from the foreground to the background, Friedrich's painting provoked an uncomfortable feeling. As usual since his controversial Das Kreuz im Gebirge (1808, The Cross on the Mountain), the position of the viewer appeared uncertain, as if floating in mid-air, finding no place to rest in the foreground, and no path to penetrate into the landscape or return to a possible valley by the mountain. It was as if humanity had not reached this higher ground where nature seemed to be untouched. According to the actor and dramaturge Karl Töpfer in 1826, this painting conveyed "... a feeling of solitude... which seizes us when seeing the image, a gloomy emptiness without solace, a standing high without being sublime." ${ }^{17}$ This last part is key because this unsettling depiction thwarts the so-called experience of the sublime. As such, this painting can be regarded, per Johannes Grave "as a surprising annulation of the aesthetic of the sublime"18 and as a fundamental critique of Richter's mountain landscape of the same motif.

Moreover, Der Watzmann can also be regarded as the continuation of Friedrich's critique of how his contemporaneous viewers engaged with landscape painting, which gave preference to a certain canon of established ideas since Lorrain and Poussin and the dispute between imitation of nature versus invention. In this sense, this painting also displays what I consider a key feature of this artist: the ability to create a distance between work and recipient, so that the imagined wandering into the landscape is both permitted and disrupted. In today's academic vocabulary in German, the term Bildbewusstsein is appropriate. To express it phenomenologically: the image knows itself to be an image and not what it depicts. In other words, the 
viewer knows that she is confronting a work of art and not standing in front of an imitation of nature. It cannot be stressed enough that among painters like Caspar David Friedrich, Philipp Otto Runge and Carl Gustav Carus there was an attempt at elevating landscape painting to a new status and with it towards a new kind of aesthetic experience and perhaps the birth of a different kind of viewer, who nevertheless did not quite flourish in the nineteenth century.

It is perhaps in Heinrich von Kleist's comment on Friedrich's Der Mönch am Meer (1808-10, The Monk by the Sea, Fig. 3) ${ }^{19}$ that an important clue about this other form of aesthetic experience can be extracted. ${ }^{20} \mathrm{~A}$ strange rendition of a seascape - the scene in this painting appeared to be inaccessible to the viewer - to be exact, not walkable between the horizontal sections of sand, sea, and sky, and above all having no proper foreground. This nothingness and uncanny viewing experience inspired Kleist's now famous and monstrous metaphor of the eyelids being cut off. But the most decisive part in his narrative is how he described the relation between the artwork and himself. He called this dynamic Anspruch and Abbruch, call and

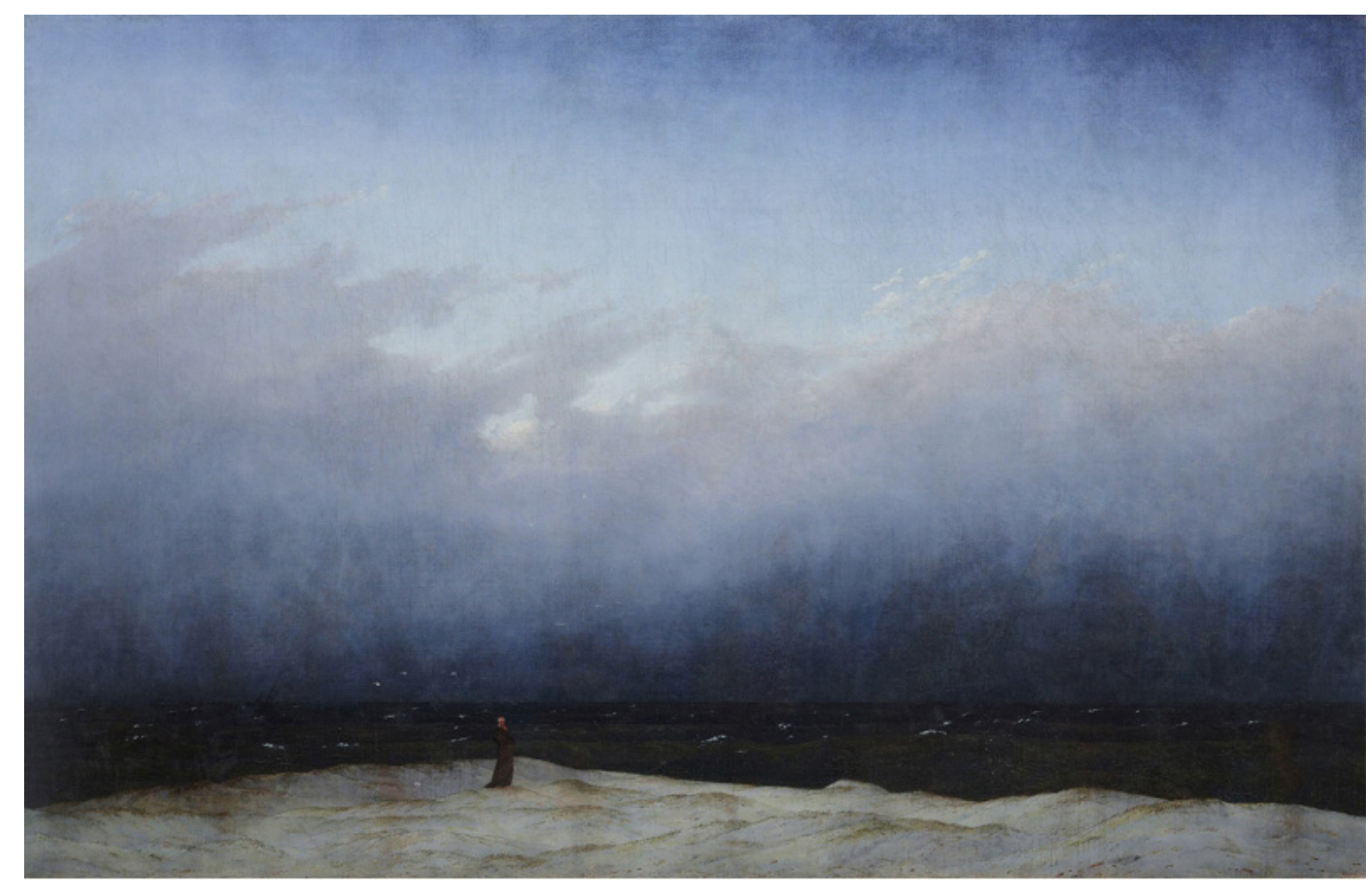

Figure 3. Caspar David Friedrich, Der Mönch am Meer, 1808-10. Oil on canvas, $110 \mathrm{x}$ $171,5 \mathrm{~cm}$. Inv. No. NG 9/85. Alte Nationalgalerie / Staatlichen Museen zu Berlin - Preußischer Kulturbesitz. Photo: Andres Kilger. CC BY-NC-SA. 
disruption, or invitation and rejection, which he experienced in front of the painting. This experience was qualitatively different from the one any spectator could have in front of an artwork that he or she likes or dislikes. Nor it was an ambivalent relationship to a specific form of art, as for instance Plato's ambivalence towards poetry ${ }^{21}$ in Book $X$ of the Republic (10.607e), finding himself attracted to it and yet withdrawing from its imaginative aspect, seeking instead to pursue a rational analysis of truth. The nature of Kleist's Abbruch is more specific because it is not an action of the viewer but of the artwork towards the viewer, a tendency to push him or her away or outside its inner realm. Thus, it was as if the image attracted his eye, but at the same time rejected him, confining his aesthetic experience to the space between himself and the painting. I would argue that it is precisely this distance between the artwork and the viewer that enables a certain uncanny quietude, which transforms this empty space into a place of decision. ${ }^{22}$ And here, in this space, is where the active participation of the viewer takes place, where the hermeneutical value of bodily experiences slowly reveals its potential.
For the eyes of today's spectators, accustomed to browsing and watching images on social media for only a second each, standing in front of Friedrich's oil painting of the Watzmann, which hangs at the Alte Nationalgalerie in Berlin, might be the contemplation of just another mountain, a rather inconspicuous landscape where there is little to see: a sparse vegetation on an otherwise bleak rocky mountain formation, with no signs of human intervention. But as has now become a general rule regarding the works of Friedrich, there is always something hidden in the surface of his canvases, something that requires more than just a careful observation to bring forward its invisible aspects. Being a relatively large-scale painting in Friedrich's œuvre, measuring 135 x 170 $\mathrm{cm}$, the large format itself prompts the viewer to keep a longer distance to have a more comprehensive view of the scene, which also happens with monumental paintings by other artists. Indeed, this aspect of the materiality of artworks, their size and format, influences the behaviour of the beholder, who cannot engage in passive contemplation and constantly needs to renegotiate her position in relation to the artwork just to see either the whole scene or details on the canvas.

But if the viewer becomes aware of her walking in front of the painting, of what happens when approaching or walking backwards away from the canvas, the painting begins to reveal an incredible mobility in the depicted landscape. From a distance, it is just another static mountain, majestic and imposing, some may say. But by approaching the canvas, it is not only possible to discover an incredible abundance of summer flowers, but also to read the movements of the wind as it passes through the grass. Friedrich had painted a visible static mountain filled with the invisibility of a summer breeze. So, by walking and oscillating between a distant and a closer look, the painting appears to oscillate between stillness and fluidity. In terms of reception aesthetics: walking back and forth in front of the painting activates the perception of an internal dynamic in the image.

Naturally, this practice of conscious walking might work only with a few paintings. To provide a different example from contemporary landscape painting, consider the works by German artist Anselm Kiefer. Here it is possible to identify how the large format 
of his monumental paintings already commands a certain kind of walking backwards, a sort of pushing the beholder away, sometimes due to actual dangerous and cutting materials embedded in the works, like lead or glass. One can, of course, trace several parallels between Kiefer and Caspar David Friedrich, but one aspect worth emphasising is this specific demand to walk in front of the artwork. An interesting contrast can be drawn from Friedrich's Gebirgslandschaft mit Regenbogen (1810, Mountain Landscape with Rainbow) ${ }^{23}$ and Kiefer's Die Deutsche Heilslinie (2012-13, The German Salvation Line, or German Salutary Line). ${ }^{24}$ Friedrich's canvas is about 1 metre on the long side, whereas Kiefer's extends to 11 metres. While in the first the beholder manages to view the whole rainbow without moving, the size of Kiefer's painting prompts the beholder to walk alongside the painting, following the path of the rainbow and reading the names of philosophers and thinkers inscribed in the painting. With every step, each of these historical figures of the late eighteenth and the whole nineteenth century become connected as the beholder walks and reads. Only then is an unforeseen aspect of the painting revealed: that following the rainbow transforms walking into an act of reading a history embedded in a landscape.

\section{Experiencing and Observing Motion}

Then there is the dance, and with it, I temporally switch to the first person. In 2014, I had the privilege of participating in a contemporary dance workshop led by Canadian dancer and choreographer Lesley Telford. There, she explained a very simple dance exercise to understand how to balance the body: one invisible thread pulls one part of the body and thereby it creates a movement, though not yet balanced. But when conceiving another invisible thread pulling another part of the body in the opposite direction, a balance is reached and consequently a dance figure is created. Thus, the

Figure 4. Arnold Böcklin, Trauer der Maria Magdalena an der Leiche Christi, 1867. Oil on canvas, 85,6 x $150 \mathrm{~cm}$. Inv. No. 104 . Kunstmuseum Basel. PD.

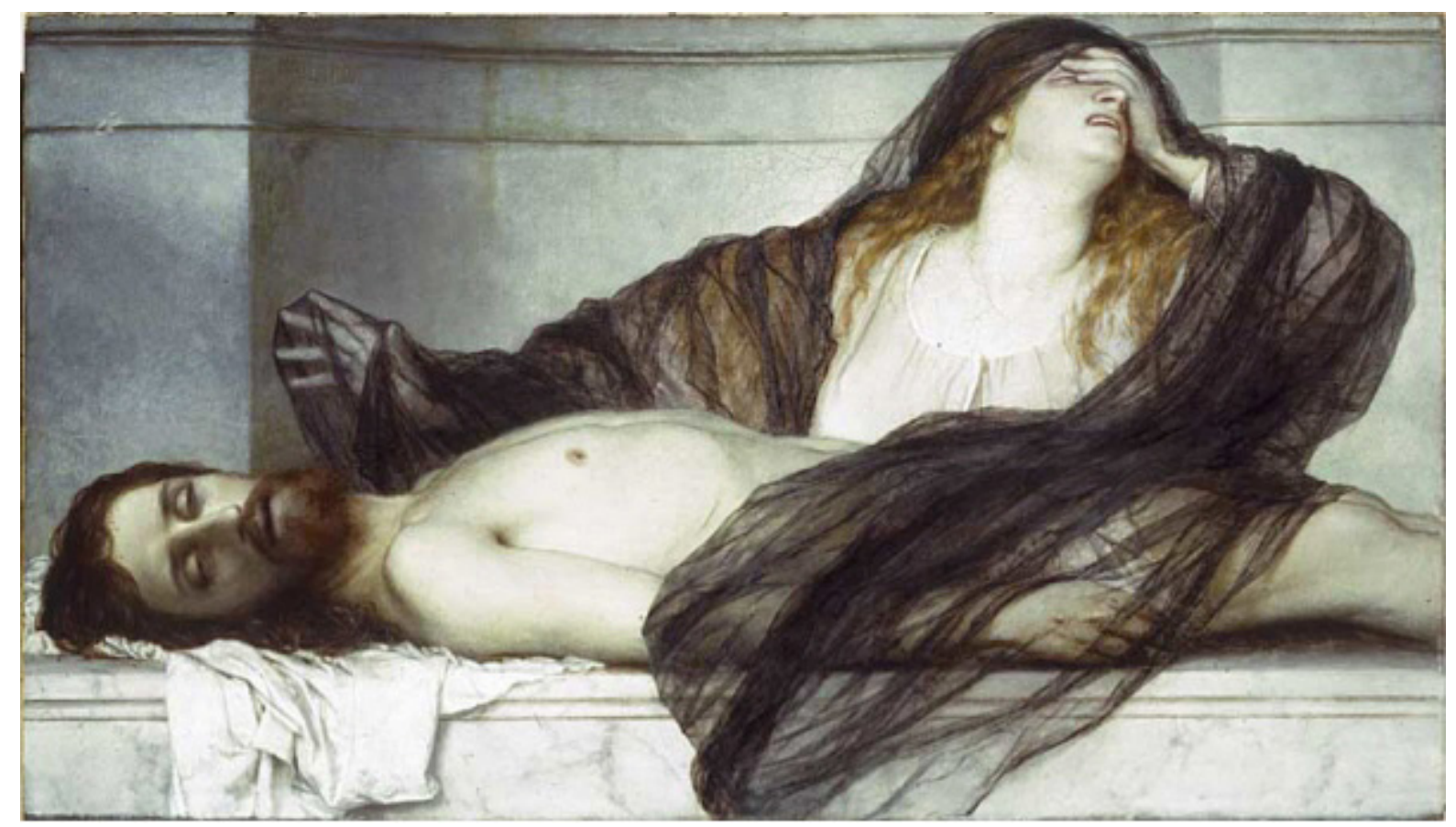


body retains both an external balance and an inner tension.

Later that year, while intensively researching Arnold Böcklin's work, and paying special attention to the postures of its human figures and the fluidity of their movements, this dance exercise proved to be of unexpected hermeneutical value in understanding something that, until then, I could not quite grasp about the painting Trauer der Maria Magdalena an der Leiche Christi (1867, Magdalene Grieving over the Body of Christ, Fig. 4). ${ }^{25}$ To any viewer, the pain and lamentation of the Magdalene is evident. But not so evident is how this figure shows a remarkable balanced fluidity despite the suffering. While her right hand appears to move insistently toward the face of her beloved, as if she is still trying to reach and touch him, her left elbow appears to be pulled in the opposite direction, as if another force were trying to take her away from this dreadful situation. ${ }^{26}$ The body of the beloved was there, but he himself was absent. The craving for the lost one contains a tension and an expansion that literally threatens to split the body of the griever. Not surprisingly, in another painting by Böcklin, a similar situation can be noticed: in Odysseus am Strande des Meeres (1869, Odysseus by the Sea), the body of the hero appears to be pulled by opposite forces. The viewer familiar with the Homeric poem and the specific scene this painting depicts might understand these forces better. ${ }^{27}$

Naturally, experiencing and/or observing bodily movements is something that we all do at different levels of awareness or intensity. But when taken as a given, it stops finding its way into the practice of art history research. The main reason is perhaps a methodological one: how to account for these bodily experiences in a (more or less) systematic way, so that they can prove their hermeneutical value? In his writings about dance, the poet and dance critic Edwin Denby recommended his hypothetical dance students a very simple exercise: to observe how people walk on the streets and see what happens..$^{28}$ One of his concerns was the difference between seeing in arts and seeing in daily life, and how the latter can nurture the way we do the former, while preserving the difference. For Denby, dancing in daily life is nothing more than the way people from different walks of life, countries and cultures walk on the streets and interact with each other. Observ- ing these situations ought to be a source of learning about forms of the human body in motion.

How do we translate daily life observations of bodily experiences to understand motion in images? One phenomenon that can be rendered visually is the movement of walking away. The exercise is simple and can be done in one or several sessions, taking simple notes: while sitting, or walking along at slow pace, to observe carefully at what happens visually when people walk away. When people pass by, we might see first their faces, then their profiles and soon they offer us a view of their backs. It is a progressive transformation through which a person slowly becomes anonymous. This experience of anonymity is more intense when the beholder only gets to see a person from behind. Sometimes, the atmospheric conditions together with the distance between viewer and moving object may intensify this phenomenon. The possibility to recognise the other decreases. And as the face becomes absent, so too the walker slowly fades away into absence. Consider what happens when we say goodbye to someone but stay still and watch them go into the distance. The 
visuality of this movement is worth noticing: slowly all the characteristics of that person, which make him or her unique, start disappearing. An inevitable loss of characteristics takes place, and only certain visible features remain, like the body posture, the position of the figure in space, and even the gait patterns. But as soon as we cannot see the other clearly anymore, we can notice that he or she appears like a dark silhouette in the distance. Weirdly enough, there is a moment in which we cannot be sure whether the other is coming back or going away, especially if we are following behind. ${ }^{29}$

I have applied this exercise to my own art history research to understand certain aspects of wandering figures seen from behind, either standing or on the move, as depicted in several paintings of nineteenth century German Romanticism. The two key aspects of this exercise are the position of the beholder in relation to the walking figure, and the movement of walking itself. When confronting side by side Carl Gustav Carus' Pilger im Felsental (after 1828/30, The Pilgrim in the Rocky Valley, Fig. 5) ${ }^{30}$ and Carl Spitzweg's Der Philosoph im Park (ca. 1860, The Philosopher in the Park, Fig. 6), ${ }^{31}$ two surrogate

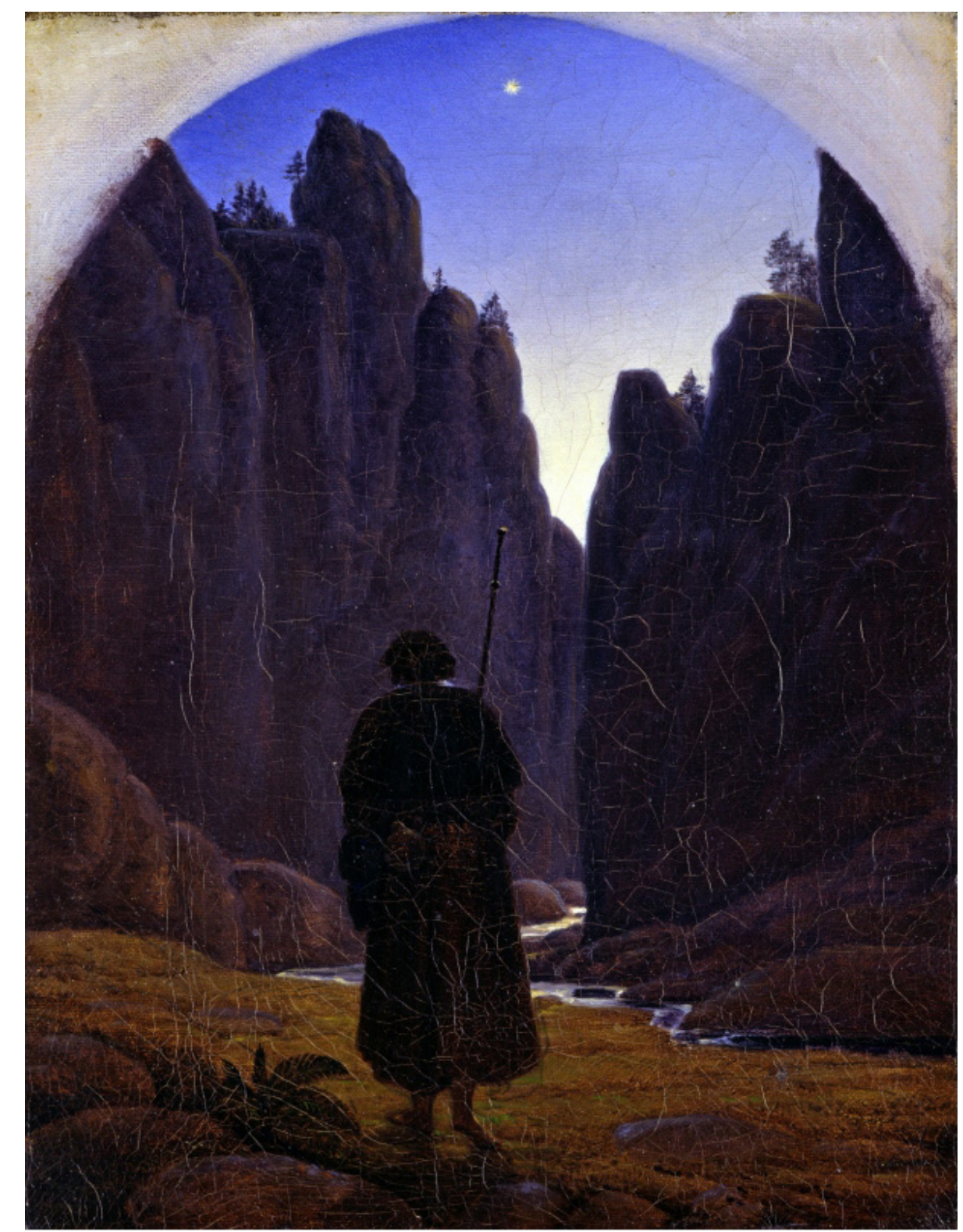

Figure 5. Carl Gustav Carus, Pilger im Felsental, after $1828 / 30$. Oil on canvas, $28 \times 22 \mathrm{~cm}$. Inv. No. A II 416. Alte Nationalgalerie / Staatlichen Museen zu Berlin Preußischer Kulturbesitz. Photo: Jörg P. Anders. CC BYNC-SA.

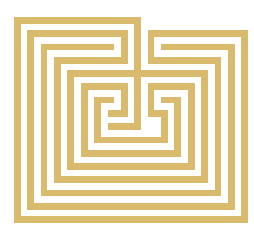




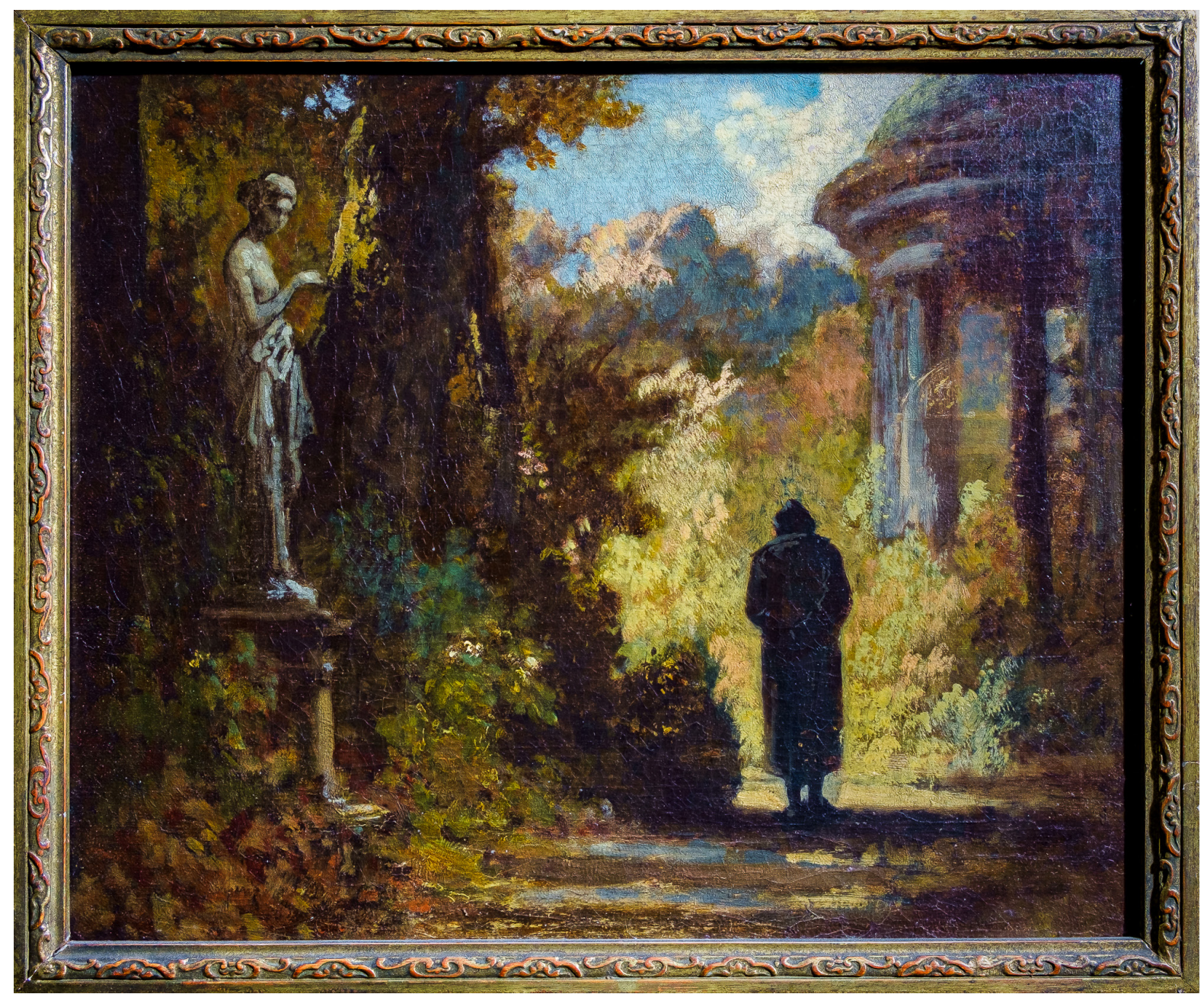

Figure 6. Carl Spitzweg, Der Philosoph im Park, ca. 1860. Oil on canvas, 27,5 x $34 \mathrm{~cm}$. Inv. No. G 0548. @ Von der Heydt-Museum, Wuppertal. Photo: Antje Zeis-Loi. figures of the wanderer with remarkable similarities, both in their depiction and their meditative slow walking, the viewer can notice that based on the composition and the perspective, the distance between beholder and figure provides two different interpretations of the event in the image. In Carus' painting, the monumental figure of the pilgrim, though obscured by the night scene, reveals a few details about his clothing and gear, as well as his being barefoot, but we do not know much about the path that he has walked until now, which thus remains uncertain. Instead, what dominates is the future and the beyond, which correlates perfectly with the idea of the pilgrimage, a wandering to the east where the sun comes, where the son of God finds his origin. For the pilgrim, the future is the experience of an original time. In Spitzweg's painting, the figure seems to be much further away from the beholder and thus its silhouette appears slightly darker and less detailed, even more so because of the contrast with the yellow autumn leaves reflecting the sunlight. Nevertheless, the painting offers a better view of the path traversed thus far, for one can see puddles on the road, which provides an idea about the atmospheric circumstances of the 
scene: it is an autumn walk after the rain. What dominates in this image is therefore the emphasis on the life here and now. Perhaps it is not all too absurd to say that this kind of analysis can reveal how these two visual examples may indeed embody concrete ideas about what the bodily experience of walking means in religious and philosophical terms.

To summarise, the practices and observations of bodily experiences discussed in this paper have been both motif and practice in artworks and among artists, respectively. As motif, they can be seen not only in depictions of pedestrians, wanderers, flaneurs, tightrope walkers, dancers and performers that populate oil paintings of different historical periods, but also in the great number of artists' sketches in preparation for their main works. As practice, the use and experience of bodily movements as part of artistic production, specifically the act of walking, although more common among contemporary artists, can be traced back to certain artists of Romanticism like Caspar David Friedrich or Carl Philipp Fohr, who took on wandering in nature not only as means to sketch in situ but also as an identity-building exercise. In this sense, this practice reveals a mobility that expands beyond the image, which not only concerns the domain of the artist, but also of the recipient, hence the realm of reception aesthetics, where the relation between artwork and spectator becomes prominent. The challenge is to consider whether this relation can be analysed in terms that surpass the intellectual or emotional level and venture into adding other forms of physical engagement into the equation.

Art historians who welcome this challenge might also welcome experiences outside the practice of art history. In terms of methodology, it is not about doing quantitative analysis of bodily experiences like walking or dancing, because the idea is not to conduct a specific number of observation protocols with precise descriptions of behaviours and their duration, as is done in psychology. But a certain level of systematicity and clear criteria about what to see is always desired, so that observation exercises become replicable and documentable if needed, and applicable to the analysis of motion both in artworks and in our work with artworks. In the case of dance and walking movements in real life and in paintings, the observer (and practitioner) may pay attention to the articulation of the different limbs of the body, the tempo and rhythm of their motion, the direction of their movements, the context where they occur, and then reflect on their visual qualities as they are translated from one artistic medium to another.

Thus, it would be easier to understand how bodily movements and their physical qualities may enable different ways of confronting images like paintings, which were not intended for this kind of active participation in the first place; to be precise, how an embodied knowledge contributes to expand the horizon of interpretation. In other words, how a sort of practical insight can expand the practice of research into art. The question remains open whether it is possible to reach the same results without these practices and observations. But I hope to have demonstrated that there is an important hermeneutical value in the conscious observation, practice and experience of bodily movements that enables new ways to approach art outside of our comfort zones. And so, we can return to the idea of the space between the beholder and the artwork as a place of decision. Because what we do in that space is what will determine how we relate to the object, and how in 
turn this object may directly affect our lives and the lives of others. The space between the beholder and the artwork is ultimately the birthplace of the ethical viewer, and it does not come at a cost to either the artist or the artwork.

\section{Notes}

1 In my book on the figure of the wanderer in nineteenth century German art, I have written extensively on the work of the above-mentioned artists, in addition to Moritz von Schwind. The book contains a great number of references that I will not repeat here. This paper summarises a few ideas from this work and presents them in a new light, further filling the gaps of an untold story about my own interdisciplinary research process. Cf. Carlos Idrobo, Das, was von uns weggeht: Abwesenheit, Zeit und das Wandermotiv in der deutschen Kunst des 19. Jahrhunderts (Hildesheim: Georg Olms, 2019). The author would like to thank the peer-reviewers of this article and the editor of this special issue for their comments and suggestions, as well as Kenneth Drummond for his proofreading and comments. 2 Cf. Wolfgang Kemp, Der explizite Betrachter: Zur Rezeption zeitgenössischer Kunst (Konstanz: Konstanz University Press, 2015), 18.

3 For a detailed presentation of the Labanotation system and how it works, including images, cf. Ann Hutchinson Guest, Labanotation: The System of Analyzing and Recording Movement, $4^{\text {th }}$ ed. (New York: Routledge, 2005). For a succinct description of Kinetography, including a very interesting parallel to Sophie Taeuber-Arp both visually and in pedagogy, cf. Flora L. Brandl, "On a Curious Chance Resemblance: Rudolf von Laban's Kinetography and the Geometric 15.
4 More on this artwork, cf. Sarah Gahr, The Art of Dance, The Andy Warhol Museum, Pittsburgh, 31 July 2015, https://www.warhol.org/the-art-of-dance/, accessed 12 May 2020.

5 Reproduced in https://www.thebroad.org/art/ andy-warhol/dance-diagram-3-lindy-tuck-turn-man accessed 12 May 2021

6 Cf. Kemp, Der explizite Betrachter, 17.

7 Cf. Education Blog, Doing the Fox Trot, 7 August 2010, Whitney Museum of American Art, https://

whitney.org/education/education-blog/doing-the-foxtrot, accessed 12 May 2020

8 Cf. Acatia Finbow, "Franz Erhard Walther, Werksatz (Workset) 2008," case study, in Performance At Tate: Into the Space of Art, Tate Research Publication, 2016, https://www.tate.org.uk/research/publications/ performance-at-tate/case-studies/franz-erhardwalther, accessed 12 May 2020.

9 About this artwork, cf. Ted Mann, "Bruce Nauman, Live-Taped Video Corridor," Collection Online at the Guggenheim, New York, https://www.quggenheim. org/artwork/3153, accessed 12 May 2020

10 Cf. Bätschmann, quoted in Kemp, Der explizite Betrachter, 67.

11 This line of argumentation follows Sherrie Levine's challenge to the idea of originality that is at the core of both her gesture of appropriation in her series After Edward Weston (1979) and After Walker Evans (1981), and her famous sentence, which echoes Roland Barthes' 'death of the author' "A painting's meaning lies not in its origin, but in its destination. The birth of the viewer must be at the cost of the painter." ("First Statement," http://www. aftersherrielevine.com/statement1.html, accessed 12 May 2020) Further on this issue, cf. Hélène Trespeuch, "The Feminism of Sherrie Levine through the Prism of the Supposed 'Death of the Author'" Archives of Women Artists, Research and Exhibitions magazine (8 June 2017), https://awarewomenartists. com/en/magazine/feminisme-de-sherrie-levineprisme-de-pretendue-mort-de-lauteur/, accessed 12 May 2020. Also Roland Barthes, "La mort de l'Auteur (1968)," in OEuvres complètes, tome II, 1966-1973 (Paris: Seuil, 1994), 495. English translation by Richard Howard in Aspen magazine, no. 5-6 (1967) available in: http://www.ubu.com/aspen/aspen5and6/ threeEssays.html\#barthes as of 12 May 2020

$12 \mathrm{~A}$ description of this experience is summarised in Ramdohr's critique against Caspar David Friedrich, and in support of Poussin's landscapes. Cf. Basilius von Ramdohr, "Über ein zum Altarblatte bestimmtes Landschaftsgemälde von Herrn Friedrich in Dresden, und über Landschaftsmalerei, Allegorie, und

Mysticismus überhaupt" (7 January 1809), in: Caspar David Friedrich in Briefen und Bekenntnissen, ed. Sigrid Hinz (München: Rogner \& Bernhard, 1974) 134. Further on Ramdohr's critique of Friedrich, cf Joseph Leo Koerner, Caspar David Friedrich and the Subject of Landscape (London: Reaktion Books, 2009), 120ff.

13 About this painting, cf. https://www.sammlung. pinakothek.de/de/artwork/QKGBPapxBb, accessed 12 May 2020

14 About this painting, cf. https://www.sammlung pinakothek.de/de/artwork/k2xnR9ExPd, accessed 12 May 2020.

15 For an extended description and interpretation of this painting, including a very interesting and important discussion in the context of early nineteenth century geognosy or historical geology, cf. Timothy Mitchell, "Caspar David Friedrich's Der Watzmann: German Romantic Landscape Painting and Historical Geology," The Art Bulletin 66, no. 3 (Sep. 1984):

\section{2-464}

16 Of course, oil painting on location became easier towards 1842, when Winsor and Newton invented their oil colours in compressible metal tubes.

17 Quoted in Johannes Grave, Caspar David Friedrich (München, London, New York: Prestel, 2012), 197. Also in Helmut Börsch-Supan \& Karl Wilhelm Jähnig, Caspar David Friedrich: Gemälde, Druckgraphik und bildmäßige Zeichnungen [Werkverzeichnis] (München: Prestel, 1973), 108. My translation. Original citation: “... ein Gefühl des Einsamseyns..., [dass] uns bei dem Beschauen des Bildes ergreift, eine düstere Leere ohne Trost, ein Hochstehn ohne erhoben seyn."

18 Grave, Caspar David Friedrich, 198. My translation. Original citation: “... überraschende Absage an die Ästhetik des Erhabenen..." 
19 About this painting, cf. . http://www.smb-digital.de/ 20 For an extensive commentary on this painting and its contemporaneous discussion, cf. Koerner, Caspa David Friedrich, 245ff.; Werner Busch, Caspar David Friedrich: Ästhetik und Religion (München: C. H. Beck, 2003), ch. 3; Grave, Caspar David Friedrich, ch. 8 .

21 Cf. Stephen Halliwell, The Aesthetics of Mimesis, Ancient Texts and Modern Problems (Princeton: Princeton University Press, 2002), 73.

22 I have previously elaborated on this idea in another article, cf. Carlos Idrobo, "He Who Is Leaving... The Figure of the Wanderer in Nietzsche's Also

sprach Zarathustra and Caspar David Friedrich's Der Wanderer über dem Nebelmeer," Nietzsche-Studien 41, no. 1 (2012): 99

23 About this painting, cf. http://collection-online. museum-folkwang. de/eMP/eMuseumPlus?service $=$ Externallnterface $\&$ module $=$ collection\&objec-

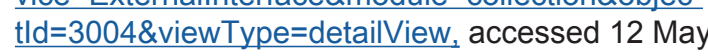
2020.

24 Reproduced in https://g.co/arts/QRNZkJsrKneocgtn8, accessed 12 May 2020.

25 About this painting, cf. http://sammlungonline. kunstmuseumbasel.ch/eMuseumPlus?service=Externallnterface\&module=collection\&objectld=3049\&viewType=detailView, accessed 12 May 2020

26 Cf. Idrobo, Das, was von uns weggeht, 225-227. 27 For a thoughtful analysis of this passage in

the Odyssey, cf. Jean-Pierre Vernant, "Ulysse en

personne," in Françoise Frontisi-Ducroux and JeanPierre Vernant, Dans l'œil du miroir (Paris: Odile Jacob, 1997). English translation by James Ker in Representations, no. 67 (Summer 1999).

28 Cf. Edwin Denby, "Dancers, Buildings, and People on the Streets" (1954) \& "Forms in Motion and in

Thought" (1965), in Dance Writings \& Poetry, ed.

Robert Cornfield (New Haven: Yale University Press, 1998), 258.

29 This whole paragraph is my own free translation and adaptation of a paragraph in my book, cf. Idrobo, Das, was von uns weggeht, 37.

30 About this painting, cf. http://www.smb-digital.

de/eMuseumPlus?service=Externallnterface\&mod-

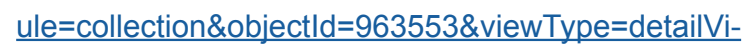
ew, accessed 12 May 2020.

31 Cf. chapter 3 of my book, Idrobo, Das, was von uns weggeht, 93-134. eMuseumPlus?service $=$ Externallnterface \&module $=$ collection\&objec$\underline{\mathrm{tld}=965511 \& \text { view Type }=\text { detailView. }}$.
Dr. Carlos Idrobo (*1979) is an affiliated researcher at the Department of Art History at the University of Turku. He focuses his research and artistic interests around topics in psychology, philosophy and arts from the nineteenth century onwards. Under the artistic name Luca Idrobo, he engages in different independent and collaborative artistic projects in documentary and artistic photography, sometimes in combination with creative writings and research. Currently, he is also a member of the research project "Liikkuvuuden rajat - konkreettinen ja kuviteltu liikkuvuus pitkällä 1800-luvulla", funded by the Jenny and Antti Wihuri Foundation and coordinated at the Department of History of the University of Jyväskylä. 